\title{
Genome-Wide Variation in DNA Methylation Predicts Variation in Leaf Traits in an Ecosystem-Foundational Oak Species
}

\author{
Luke Browne $^{1,2}$, Brandon MacDonald ${ }^{1}{ }^{(\mathbb{C}}$, Sorel Fitz-Gibbon ${ }^{1}{ }^{(}$, Jessica W. Wright ${ }^{3}$ and Victoria L. Sork ${ }^{1,4, *}$ \\ 1 Department of Ecology and Evolutionary Biology, Charles E. Young Drive, University of California, Los \\ Angeles, CA 90095-1438, USA; luke.browne@yale.edu (L.B.); brandonwsmacdonald@gmail.com (B.M.); \\ sorel@ucla.edu (S.F.-G.) \\ 2 UCLA La Kretz Center for California Conservation Science, Institute of the Environment and Sustainability, \\ University of California, Los Angeles, CA 90095-1496, USA \\ 3 USDA-Forest Service Pacific Southwest Research Station, 1731 Research Park Dr., Davis, CA 95618, USA; \\ jessica.w.wright@usda.gov \\ 4 Institute of the Environment and Sustainability, University of California, Los Angeles, CA 90095-1496, USA \\ * Correspondence: vlsork@ucla.edu
}

Citation: Browne, L.; MacDonald, B.; Fitz-Gibbon, S.; Wright, J.W.; Sork,

V.L. Genome-Wide Variation in DNA Methylation Predicts Variation in Leaf Traits in an Ecosystem-Foundational Oak Species. Forests 2021, 12, 569. https://doi.org/10.3390/f12050569

Academic Editors: Mary Ashley and Janet R. Backs

Received: 26 March 2021

Accepted: 29 April 2021

Published: 1 May 2021

Publisher's Note: MDPI stays neutral with regard to jurisdictional claims in published maps and institutional affiliations.

Copyright: (c) 2021 by the authors. Licensee MDPI, Basel, Switzerland. This article is an open access article distributed under the terms and conditions of the Creative Commons Attribution (CC BY) license (https:// creativecommons.org/licenses/by/ $4.0 /)$.

\begin{abstract}
Epigenetic modifications such as DNA methylation are a potential mechanism for trees to respond to changing environments. However, it remains controversial the extent to which DNA methylation impacts ecologically important traits that influence fitness. In this study, we used reduced-representation bisulfite sequencing to associate genomic and epigenomic variation with seven phenotypic traits related to growth, leaf function, and disease susceptibility in 160 valley oak (Quercus lobata) saplings planted across two common gardens in California. We found that DNA methylation was associated with a significant fraction of phenotypic variance in plant height, leaf lobedness, powdery mildew infection, and trichome density. Two of the seven traits were significantly associated with DNA methylation in the CG context, three traits were significantly associated with CHG methylation, and two traits were significantly associated with $\mathrm{CHH}$ methylation. Notably, controlling for genomic variation in SNPs generally reduced the amount of trait variation explained by DNA methylation. Our results suggest that DNA methylation may serve as a useful biomarker to predict phenotypic variation in trees, though it remains unclear the degree to which DNA methylation is a causal mechanism driving phenotypic variation in forest tree species.
\end{abstract}

Keywords: phenotype; DNA methylation; Quercus; single nucleotide polymorphisms; functional traits; leaf traits; bisulfite sequencing

\section{Introduction}

Due to rapidly changing environmental conditions caused by drivers of global change, understanding the potential role of epigenetics in plant response to the environment has become a topic of interest for ecologists and evolutionary biologists [1-5]. DNA methylation, where cytosine bases are methylated by distinct molecular pathways in either the $\mathrm{CG}, \mathrm{CHG}$, or $\mathrm{CHH}(\mathrm{H}=\mathrm{C}, \mathrm{A}$, or $\mathrm{T})$ sequence contexts, is a prominent epigenetic modification $[4,6,7]$ that may play a role in adaptive phenotypic responses to the environment [8-11]. In addition, phenotypic traits mediated by DNA methylation can be heritable [10,12-16], providing the raw material for evolution to occur and a mechanism for induced phenotypic responses to the environment to persist across generations. Several studies have shown DNA methylation to be associated with phenotypic traits, such as drought tolerance in Arabidopsis [10], flowering time in flax [17], adaption to temperature in Arabidopsis [18], and various traits in other herbaceous species $[10,17,19,20]$. However, studies resolving the associations between DNA methylation and phenotype are less common in tree species despite the advantages epigenetic modifications may bring for plants with long lifespans to be able to respond phenotypically to rapid climate change [21]. 
Forest tree species are among the most economically and ecologically important plant taxa globally, and understanding their epigenetic response to changing conditions is critical [22-24]. In particular, oaks (Quercus spp.) are foundational members of many ecosystems, having higher biomass and species diversity than any other woody genus in the United States and Mexico [25]. Previous studies of DNA methylation in oaks have explored natural variation across populations in Quercus lobata [26,27], drought stress in Quercus ilex [28], temperature stress in Quercus suber [29], cork quality in Quercus suber [30], and seedling growth and gene expression in Quercus lobata [31]. These studies are complemented by research in other woody tree species, such as Picea abies [32], Populus trichocarpa [33], Eucalpytus [34], Pistacia lentiscus [35], and Ilex aquifolium [36] ranging in focus from the effects of temperature on embryogenesis, drought stress, epigenetic differences among clonal genotypes, and associations between epigenetic variation and leaf phenotype. Continuing to study the role of epigenetic modifications in woody species is critical to assessing the extent to which DNA methylation shapes plant phenotype [21].

If DNA methylation is providing a mechanism for plant response to the environment, there must be a causal link between variation in DNA methylation and plant phenotype. In some cases, DNA methylation is known to play a causal role in regulating gene expression and variation in phenotypic traits [37-39]. However, the general connection between DNA methylation and phenotype remains unresolved [40]. For example, in one Arabidopsis study, gene expression did not change consistently with the loss of gene body methylation (gbM [41]), which is consistent with other evidence that gbM shows no functional relationship with gene expression. However, analysis of multiple accessions of Arabidopsis indicates that gbM is a heritable trait "consistent with the hypothesis that gbM is the result of a passive process related to the variation in the robustness of the maintenance of heterochromatin", which may lead to the evolution of epialleles that shape phenotypes [16]. In tomato, experimental studies showed that grafting root stock with epigenetic variation associated with msh1 affected growth that was heritable over five generations [42]. An important first step for natural tree populations would be to establish an association (not necessarily causal) between phenotypic variation at ecologically important plant traits and variation in DNA methylation.

Variation in DNA methylation may or may not be independent from underlying genetic variation in DNA sequence, which further complicates efforts to resolve the role of DNA methylation on phenotype. Statistically, it is possible to account for this connection by controlling for DNA sequence variation, often in the form of SNPs (single nucleotide polymorphisms), in any association analyses between DNA methylation and phenotype. Genomic relationship matrices are commonly used to estimate the proportion of phenotypic variance in a trait explained by all measured SNP or DNA methylation markers $[43,44]$. This approach works especially well for complex, polygenic traits that are controlled by many sites across the genome, although SNPs have limitations. For example, transposable element insertion polymorphisms (TIPS) can also shape phenotypic diversity and these many not be associated with SNPs [45]. Nonetheless, it is instructive to analyze the genomic and epigenomic basis of complex traits through simultaneous estimation of phenotypic variance from relationship matrices generated from both SNPs and DNA methylation markers [46,47]. In this way, it is possible estimate the association between DNA methylation and phenotypic traits while controlling for potential underlying genetic variation.

In this study, we tested the association between DNA methylation and phenotypic traits in a widely distributed, endemic California oak, Quercus lobata (valley oak) as a first step in finding candidate phenotypes potentially influenced by epigenetic processes. Previous studies of valley oak have revealed strong associations between climate gradients and variation in DNA methylation across the genome [26,27] and reduced seedling growth and altered gene expression when DNA methylation is inhibited experimentally [31]. Moreover, oaks have an unusual pattern of DNA methylation where subcontext-specific patterns of DNA methylation associated with transposable elements reveal that the genome 
has broadly distributed heterochromatin in intergenic regions [48], which is a pattern more similar to grasses than to other angiosperms [49]. Using data from 160 valley oak saplings planted across two common gardens in California, we addressed the following questions: Is there an association between DNA methylation and plant growth and leaf traits? How does this relationship vary by sequence context? If we control for the underlying genetic variation across individuals, do associations between DNA methylation and phenotypic traits remain? In addition, we perform a series of data simulations to test the power and precision of our analysis approach in an effort to guide future studies.

\section{Materials and Methods}

\subsection{Study Species}

Quercus lobata Née (valley oak) is an ecosystem-foundational oak species endemic to California that occurs along the foothills of the Sierra Nevada and Coastal mountain ranges (Figure 1). As a dominant species in woodlands and savannas, valley oak has high ecological importance [50], in addition to its high cultural value to Native Americans [51]. In general, valley oak populations have high local genetic diversity, low genetic structure, and significant associations between genotypic and climatic gradients across its range [52,53]. Previous studies of valley oak suggest that DNA methylation may be involved in local adaptation to climate, especially in the CG context, which shows high differentiation among populations and strong associations with temperature gradients [26,27].

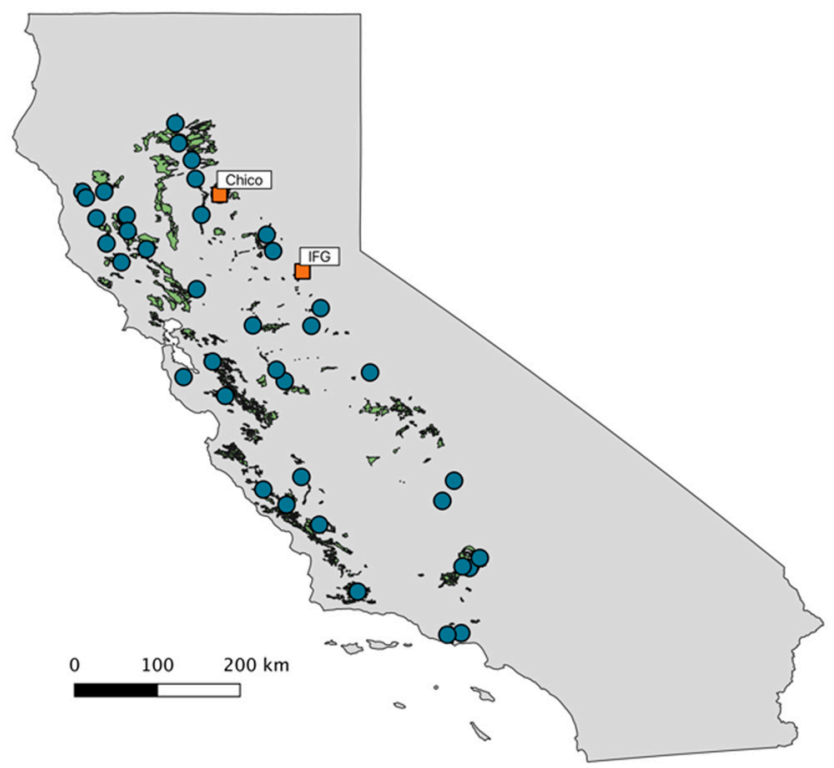

Figure 1. Map of provenances (blue circles) individuals sampled in this study across the range of valley oak in California (green polygons). Orange rectangles show location of the two common gardens in Chico and Placerville (IFG), California.

\subsection{Valley Oak Provenance Trial}

All phenotypic and sequencing data used in this study come from the valley oak provenance trial, and the full details on the design and establishment of the valley oak provenance trial are available in [54]. In 2012, >10,000 open-pollinated acorns were collected from 674 adult valley oaks in 95 localities distributed across the species range. These acorns were germinated in a greenhouse and in 2014, 6945 seedlings were planted at two sites in Placerville (IFG) and Chico, California (Figure 1). Seedlings were planted with $2.25 \mathrm{~m}$ spacing intervals in a blocked design, such that each family (i.e., half-sib progeny collected as acorns from a single adult) had at least one individual in each block at each site. Both sites were irrigated and weeded to increase the probability of seedling establishment, as is commonly done in provenance trials. 


\subsection{Phenotypic Measurements}

In 2016, when saplings were approximately four years old, we measured a set of seven phenotypic traits related to performance and leaf function: height of the tallest stem $(\mathrm{cm})$, leaf area $\left(\mathrm{cm}^{2}\right)$, leaf lobedness, specific leaf area $\left(\right.$ SLA, $\left.\mathrm{cm}^{2} \mathrm{~g}^{-1}\right)$, leaf thickness $(\mathrm{mm})$, trichome density (categorical, see below), and powdery mildew infection intensity (categorical, see below) [55]. Height of the tallest stem in valley oak seedlings is strongly correlated with other metrics of size and growth, such as diameter at breast height (dbh), and likely plays a key role in early stage survival for avoiding herbivory and surviving abiotic stress [56]. For leaf traits, we sampled mature leaves that were $\sim 10 \mathrm{~cm}$ from the branch tip from each side of the tree. We used one leaf sample per individual for estimating trichome density, two samples for leaf thickness and 4-5 leaves per individual for leaf area, specific leaf area, and leaf lobedness. Pairwise correlations among phenotypic traits were all $R<0.46$ (Table 1 ).

Table 1. Pairwise correlations between phenotypic traits measured on valley oak individuals in this study. The bottom diagonal shows the estimated Pearson's correlation coefficient $(R)$ between pairs of traits.

\begin{tabular}{|c|c|c|c|c|c|c|c|}
\hline Trait & Height & Leaf Area & $\begin{array}{c}\text { Leaf } \\
\text { Lobedness }\end{array}$ & $\begin{array}{c}\text { Specific Leaf } \\
\text { Area }\end{array}$ & $\begin{array}{c}\text { Leaf } \\
\text { Thickness }\end{array}$ & $\begin{array}{l}\text { Trichome } \\
\text { Density }\end{array}$ & $\begin{array}{l}\text { Powdery } \\
\text { Mildew }\end{array}$ \\
\hline Height & 1.00 & & & & & & \\
\hline Leaf area & 0.46 & 1.00 & & & & & \\
\hline Leaf lobedness & 0.25 & 0.34 & 1.00 & & & & \\
\hline Specific leaf area & -0.14 & 0.04 & 0.01 & 1.00 & & & \\
\hline Leaf thickness & -0.15 & 0.18 & -0.10 & -0.19 & 1.00 & & \\
\hline Trichome density & 0.29 & -0.06 & -0.19 & -0.19 & -0.05 & 1.00 & \\
\hline Powdery mildew & 0.44 & 0.17 & -0.05 & -0.06 & -0.11 & 0.16 & 1.00 \\
\hline
\end{tabular}

We measured leaf area by scanning fully hydrated leaves and estimating area using the Image software [57]. To estimate leaf lobedness, we estimated leaf perimeter using ImageJ and then divided leaf perimeter ${ }^{2}$ by leaf area. Leaf lobedness in oaks is negatively associated with hydraulic resistance and may be a mechanism for optimizing water balance under dry conditions [58]. We then pressed and dried the leaves to calculate SLA (leaf area divided by dried mass) [59]. Higher SLA has been shown to be related to higher leaf nitrogen concentration, higher potential relative growth rates, and lower leaf longevity and lower investment in secondary compounds [59]. We measured leaf thickness at the midpoint between the perimeter and midrib, midway between the base and the tip using digital calipers, making sure to avoid secondary veins, as recommended by [59]. Higher leaf thickness is related to longer leaf longevity, higher toughness, higher photosynthetic capacity per unit leaf area, and leaf nitrogen per unit area, which may be advantageous when under high levels of moisture availability $[59,60]$. We estimated trichome density by viewing the abaxial side of the leaf under a microscope at $1500 \times$ magnification following [61] and [62] and categorizing trichome density into 6 categories: $<15,15-24,25-34$, $35-44,45-54$, and $\geq 55$ trichomes in the field of view. Higher trichome densities reduce water loss by decreasing the rate of transpiration and may be advantageous in dry conditions [63]. We categorized powdery mildew infection based on the proportion of leaves on the entire sapling displaying signs of infection: no signs of infection, low infection $(<33 \%$ of leaves infected), medium infection (33-66\% of leaves infected), high infection ( $>66 \%$ of leaves displaying sign of infection).

We analyzed the relationship between SNP, methylation, and phenotypic variation using both raw phenotypic trait values and phenotypic trait values adjusted to control for local environmental effects of each common garden. Raw phenotypic values include the potential contribution of environmentally induced DNA methylation on phenotypic traits, while the adjusted phenotypic values include the contribution of DNA methylation to a phenotypic trait after controlling for local environmental effects. To accomplish this, we fit a separate linear regression for each phenotypic trait using the phenotypic trait as the response variable and common garden location and block nested within common garden 
location as random effects using the 'lmer' function in the 'lme4' R package [64]. We then took the residuals of each model as the adjusted phenotypic values.

\subsection{Bisulfite Sequencing}

We chose 160 focal saplings for bisulfite sequencing, where we simultaneously identified genomic SNPs and variation in DNA methylation across the genome using the same DNA sample (see below). The saplings came from a total of 40 maternal families, sampling 2 progeny from each family in each planting site. We followed the same bisulfite sequencing protocol described elsewhere [27]. Briefly, we extracted total genomic DNA from leaf tissue using a prewash protocol [65] and the Qiagen Dneasy plant extraction kit. We modified the protocol of Feng et al. [66] to prepare reduced-representation bisulfite sequencing (RRBS) libraries. We first digested total genomic DNA with Mspl (CCGG) that was then end-repaired and adenylated with Klenow fragments ( $3^{\prime}$ to $5^{\prime}$ exo-). We ligated Illumina TruSeq adapters to fragments in each library. We performed size selection using AMPureXP beads to target fragments of 200 to $500 \mathrm{bp}$ (including 120 bp of adapter sequence). We treated libraries with sodium bisulfite (EpiTect, Qiagen) to perform the conversion of unmethylated cytosines to uracil, which then are subsequently read as thymine during sequencing. The prepared libraries were PCR amplified with Illumina primers and then pooled in batches of 12. Pooled libraries were sequenced on multiple lanes on an Illumina HiSeq 2000 v3 in 100-bp single end mode at the core facilities of the Broad Stem Cell Center, UCLA.

\subsection{Methylation and SNP Calling}

We filtered Illumina reads that failed the Illumina chastity test and then converted from QSEQ to FASTQ format, demultiplexed by sample, and applied the EAMSS quality score correction. We used TrimGalore (https://github.com/FelixKrueger/TrimGalore, accessed on 31 October 2019) in 'rrbs' mode to trim 3-4 bases at the ends of reads after examining mbias plots generated in MethylDackel (https://github.com/dpryan79/MethylDackel, accessed on 31 October 2019), ensuring reads were at least 20 bases with a quality score of 20. We aligned trimmed reads using bwa-meth [67] to v3.0 of the valley oak genome [68] using default settings. We extracted the methylation levels separately for the CG, CHG, and $\mathrm{CHH}$ context using MethylDackel, with minimum mapping quality of 40, a minimum depth of coverage of $10 \times$, and a maximum depth of coverage of $1000 \times$. These methylation levels range from 0 to 1 and estimate the fraction of cells containing DNA methylation at a locus for a given sample. We filtered methylation sites such that each site had $<10 \%$ missing data and had a standard deviation $>0.01$, to select for variable sites. We then removed any methylation site that had a high correlation $\left(R^{2} \geq 0.70\right)$ with any other methylation site in the same sequence context within $500 \mathrm{bp}$ until no such pairs remained, leaving a set of uncorrelated methylation sites. To reduce the influence of extreme methylation levels at individual samples in analysis, we winsorized methylation levels at each site using the 'Winsorize' function in the DescTools R package [69]. Winsorizing limits extreme values in a dataset and reduces the effect of spurious outliers by setting all data below the 5th percentile to the 5th percentile and all data above the 95th percentile to the 95th. Finally, we removed two individual valley oaks for having $\geq 25 \%$ missing data across all methylation sites. After filtering, we obtained $6175 \mathrm{mCG}, 2831 \mathrm{mCHG}$, and $4350 \mathrm{mCHH}$ variable and high-quality methylation sites across the valley oak genome.

To call SNPs from the RRBS reads [70], we used the BISulfite-seq CUI Toolkit (BISCUIT) (https:/ / github.com/zhou-lab/biscuit, accessed on October 31 2019). We set a minimum base quality of 20 and mapping quality of 20 during SNP calling. We then used the Genome Analysis Tool Kit [71] to filter variants with an allele count AC $<4$, allele frequency AF $<0.10$, and genotype quality GQ $<20$. We further filtered SNPs using vcftools [72] such that all SNPs were biallelic, had $<10 \%$ missing data, minor allele frequency $>0.05$, and a mean depth of coverage over all individuals $\geq 5 \times$ and $\leq 500 \times$. To reduce the occurrence of spurious SNP calls from the RRBS reads, we used vcftools to exclude variants that were 
out of Hardy-Weinberg Equilibrium with $p<0.0000001$. Then, we used plink [73] to filter for linkage disequilibrium among SNPs, similar to the methylation sites, where a SNP was removed if it was highly correlated $\left(R^{2} \geq 0.70\right)$ with any other SNP in a 500 bp window until no such pairs remain. After filtering, we retained 8450 high quality and variable SNPs.

\subsection{Trait Associations}

To determine the association between DNA methylation and our set of phenotypic traits, we used the GCTA (Genome-wide Complex Trait Analysis) software [47]. GCTA estimates the proportion of phenotypic variance of a trait explained by genomic data (e.g., SNP or DNA methylation data) using relatedness matrices and genome-based restricted maximum likelihood (GREML) [44]. The use of relatedness matrices to explain variation in complex traits has grown recently in ecology and evolutionary biology $[43,46]$ due to the increasing availability of reduced representation sequencing that is well-suited for these types of analyses. Additionally, GCTA is able to estimate the separate contributions of multiple relatedness matrices to phenotypic variance. In this way, we were able to separate the amount of phenotypic variance explained by DNA methylation after controlling for underlying genetic variation in the sampled SNPs. Importantly though, SNPs outside of the sampled sequences may still play an important role in predicting phenotypic variation, which would not be accounted for due to lack of sampling. The approach does not relate individual SNPs or methylation sites to individual traits, but rather uses variation in SNPs and DNA methylation sampled across the entire genome to predict phenotype.

We calculated relatedness matrices from the SNP and DNA methylation for each sequence context separately (e.g., CG, CHG, CHH) using OSCA (OmicS-data-based Complex trait Analysis) [74]. In all model runs, we included the first 2 principal components of the relatedness matrix or matrices included in the analysis to help control for population stratification (Figure S1). We also included mean depth of coverage to control for differences in sequencing coverage among individuals. Mean depth of coverage across sites was highly correlated across SNP, CG, CHG, and CHH sites (Pearson's $R>0.98$ for all comparisons), and thus for simplicity we only used depth of coverage at SNP sites as a covariate in the GCTA analysis. We used the expectation-maximization restricted maximum likelihood (EM-REML) algorithm option with no constraint and 10,000 maximum iterations to aid in model convergence.

We included 154 saplings in the final trait analyses (two excluded for missing methylation data and four excluded for missing trait data). With this sample size, we expect high uncertainty and low power to detect trait associations. However, our goal in this study was to determine if there is a detectable association between DNA methylation, SNPs, and phenotypic traits, rather than precisely estimate the amount of variance DNA methylation can explain, which would require much larger sample sizes. To this end, we used a permutation-based approach to test whether the amount of variance explained by SNPs or DNA methylation in each phenotypic trait was higher than would be expected by chance, under the null hypothesis that there was no association between SNPs, DNA methylation, and our phenotypic traits, following the approach of [75]. To accomplish this, for each model run, we randomized phenotypes among individuals $n=10,000$ times and in each iteration calculated the percent of variance explained by DNA methylation and SNPs in permuted phenotypes. We compared this null distribution of expected percent variance explained in phenotypes with the observed phenotypic variance explained in the observed data. If the observed amount of phenotypic variance was $>95 \%$ of permuted values, we interpret this as a signal of a significant association between the trait of interest and DNA methylation of SNP variation. If more than one relatedness matrix was included in the model run, we separately estimated the null distribution of phenotypic variance explained for each matrix.

Additionally, we performed a series of data simulations to test the validity and power of our permutation-based approach. We simulated a series of different scenarios that varied the number of individuals sampled and the amount of trait variance explained 
by either SNP or DNA methylation variation. In each simulation repetition, we first simulated a SNP dataset with 1000 markers all with minor allele frequency $>0.05$. We then simulated a set of 1000 DNA methylation markers that varied in methylation levels from 0.0-1.0 at each marker. We next simulated independent polygenic additive effect sizes for each SNP and methylation marker that was then used to simulate a phenotypic trait. The effect sizes of SNP and methylation markers were independent from each other as well. We varied the true amount of variance in the phenotypic trait explained by either the SNP or DNA methylation markers from 0.00001 (required to be a non-zero number), $0.10,0.20,0.30,0.40$. We also varied the number of individuals being simulated from 50 , 150, 250, 500, to 1000 individuals. For each parameter combination, we employed the permutation-based testing approach described above for detecting a significant effect of either SNP or DNA methylation in predicting trait variation. We simulated 100 repetitions of each parameter combination. We combined the results to calculate false positive rates when DNA methylation explained close to 0 trait variance and the statistical power of the permutation-based approach when a non-zero amount of trait variance was explained by DNA methylation across sample sizes.

\section{Results}

Overall, DNA methylation alone in any context without controlling for genetic variation explained a significant fraction of variance in four of the seven traits we measured (Figure 2). However, the amount of trait variation explained by DNA methylation was generally reduced and often was no longer statistically significant after controlling for genetic variation (Figure 2). The few exceptions to this pattern were CHG and $\mathrm{CHH}$ methylation predicting plant height and CHG methylation predicting extent of powdery mildew infection, which both explained a significant fraction of trait variation even after controlling for genetic variation (Figure 2). Traits varied in which DNA methylation contexts were able to explain variation, with some traits associated with CG methylation (e.g., leaf lobedness, trichome density), others with CHG methylation (e.g., height, extent of powdery mildew infection, trichome density), and others with $\mathrm{CHH}$ methylation (e.g., height, trichome density, Figure 2). Leaf area, specific leaf area, and leaf thickness did not show significant associations with DNA methylation in any context (Figure 2). SNP variation explained a significant fraction of trait variation for leaf area, leaf lobedness, and trichome density (Figure 2).

Adjusting phenotypic trait values for local environmental effects (i.e., controlling for variation across common garden sites and among blocks within sites) affected estimates of the amount of variation explained primarily for height, trichome density, and extent of powdery mildew infection (Figure 2). In these cases, adjusted phenotypes showed weaker associations with variation in DNA methylation when local environmental effects were accounted for (Figure 2). The amount of trait variation explained by SNPs was not affected by controlling for local environmental effects (Figure 2).

Using simulated data, we found that our analysis approach of permuting phenotypes to simulate the null hypothesis of no association between SNP or DNA methylation data and traits had an acceptable false discovery rate $(\sim 5 \%)$ for testing the null hypothesis of no association between trait variation and SNP/DNA methylation variation at sample sizes similar to those used in this study ( $n=150$ individuals, Figure 3$)$. However, the analysis approach had low power to detect associations (e.g., $20 \%$ power to detect association if DNA methylation explains $30 \%$ of trait variance) at these sample sizes (Figure 3). Furthermore, we found high levels of variation and uncertainty in the estimates of variation explained when sample sizes were $<500$ individuals (Figure S2). 


\begin{tabular}{|c|c|c|c|c|c|c|c|}
\hline & \multicolumn{7}{|c|}{$\begin{array}{l}\text { Trait and DNA methylation / SNP associations } \\
\text { (percent variance explained) }\end{array}$} \\
\hline & SNP & $\mathrm{mCG}$ & mCG I SNP & $\mathrm{mCHG}$ & $\mathrm{mCHG}$ I SNP & $\mathrm{mCHH}$ & $\mathrm{mCHH}$ I SNP \\
\hline Height & $1 \%(0.22)$ & $3 \%(0.35)$ & $2 \%(0.6)$ & $94 \%{ }^{*}(0.36)$ & $96 \%{ }^{*}(0.39)$ & 76\%* (0.45) & $79 \%^{*}(0.47)$ \\
\hline Height (adjusted) & $2 \%(0.22)$ & $6 \%(0.35)$ & $4 \%(0.6)$ & $12 \%(0.39)$ & $16 \%(0.43)$ & $7 \%(0.46)$ & $6 \%(0.49)$ \\
\hline Leafarea & $47 \% \%^{*}(0.25)$ & $48 \%(0.37)$ & $9 \%(0.6)$ & $18 \%(0.39)$ & $7 \%(0.41)$ & $3 \%(0.46)$ & $2 \%(0.47)$ \\
\hline Leafarea (adjusted) & $59 \% *(0.25)$ & $58 \%(0.38)$ & $5 \%(0.59)$ & $16 \%(0.39)$ & $3 \%(0.4)$ & $2 \%(0.46)$ & $1 \%(0.46)$ \\
\hline Lobedness & $60 \% *(0.25)$ & $87 \% *(0.37)$ & $53 \%^{*}(0.58)$ & $14 \%(0.39)$ & $9 \%(0.4)$ & $9 \%(0.47)$ & $6 \%(0.45)$ \\
\hline Lobedness (adjusted) & $76 \% *(0.24)$ & $91 \%^{*}(0.37)$ & $31 \%(0.57)$ & $10 \%(0.39)$ & $4 \%(0.38)$ & $10 \%(0.47)$ & $5 \%(0.44)$ \\
\hline Mildew & $2 \%(0.22)$ & $6 \%(0.35)$ & $4 \%(0.6)$ & $64 \%^{*}(0.38)$ & $63 \%^{*}(0.42)$ & $20 \%(0.47)$ & $22 \%(0.49)$ \\
\hline Mildew (adjusted) & $9 \%(0.23)$ & $12 \%(0.36)$ & $7 \%(0.61)$ & $42 \%(0.39)$ & $34 \%(0.43)$ & $4 \%(0.46)$ & $4 \%(0.49)$ \\
\hline Sla & $17 \%(0.24)$ & $44 \%(0.37)$ & $38 \%(0.61)$ & $58 \%(0.39)$ & $49 \%(0.42)$ & $24 \%(0.47)$ & $21 \%(0.49)$ \\
\hline Sla (adjusted) & $23 \%(0.24)$ & $50 \%(0.37)$ & $39 \%(0.61)$ & $63 \%(0.38)$ & $53 \%(0.42)$ & $26 \%(0.47)$ & $23 \%(0.49)$ \\
\hline Thickness & $7 \%(0.23)$ & $5 \%(0.35)$ & $4 \%(0.6)$ & $7 \%(0.39)$ & $5 \%(0.42)$ & $10 \%(0.47)$ & $6 \%(0.49)$ \\
\hline Thickness (adjusted) & $12 \%(0.23)$ & $5 \%(0.35)$ & $4 \%(0.6)$ & $4 \%(0.39)$ & $3 \%(0.42)$ & $7 \%(0.46)$ & $4 \%(0.49)$ \\
\hline Trichome & $90 \% *(0.22)$ & $76 \% *(0.37)$ & $4 \%(0.55)$ & $84 \% \%^{*}(0.37)$ & $21 \%(0.38)$ & $85 \% \%^{*}(0.44)$ & $17 \%(0.43)$ \\
\hline Trichome (adjusted) & $93 \% *(0.22)$ & $85 \% \%^{*}(0.37)$ & $4 \%(0.55)$ & $69 \%^{*}(0.38)$ & $5 \%(0.37)$ & $38 \%(0.47)$ & $2 \%(0.41)$ \\
\hline
\end{tabular}

Figure 2. Percent of variance explained in seven traits of valley oak by variation in SNPs and each DNA methylation context. 'mCGISNP', 'mCHGISNP', and 'mCHHISNP' indicate the percent variance explained by each methylation context after controlling for genetic variation in the SNPs. Standard errors are indicated in parentheses. Trait values were either the raw phenotypic values or the adjusted values after controlling for site and block effects in the common gardens. Bolded values with asterisks indicate significant associations $(p<0.05)$ from a permutation-based approach. Darker shadings of blue indicate higher values of percent variance explained.

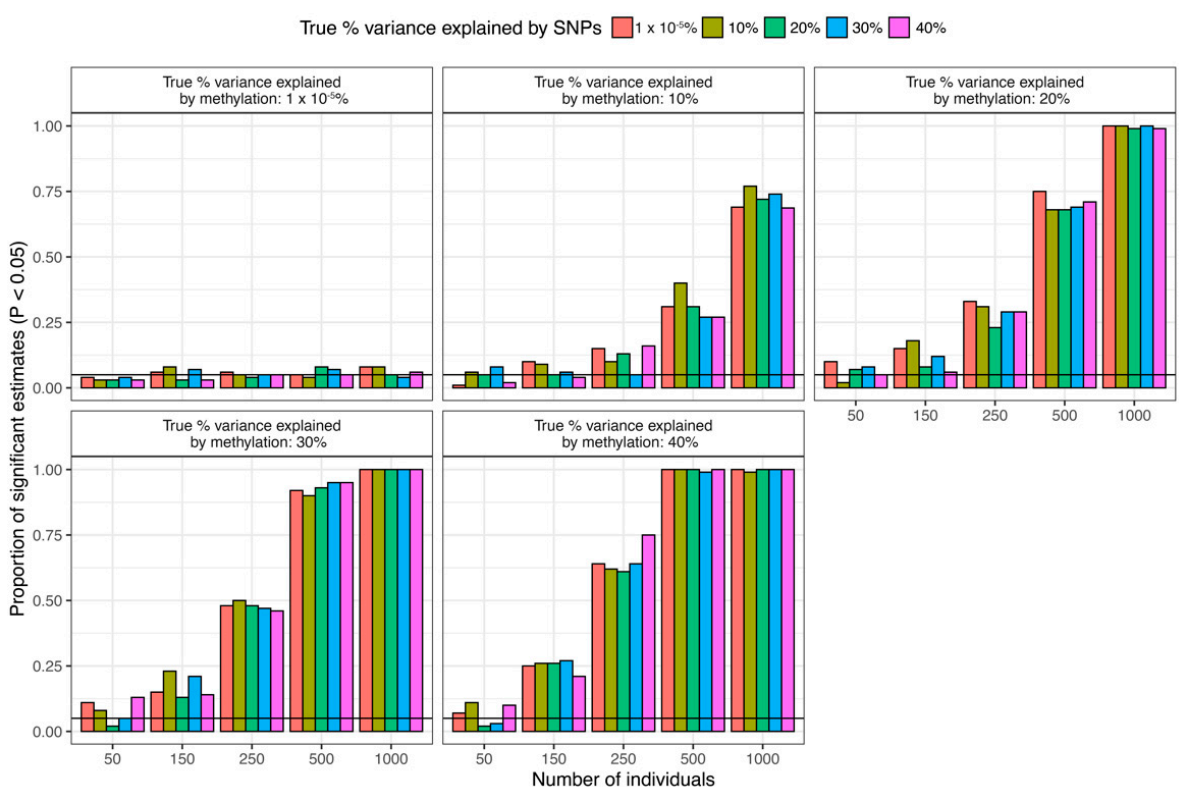

Figure 3. Statistical power increases with sample sizes and is generally not affected by the amount of variance explained by SNPs. Proportion of significant estimates of the relationship between simulated DNA methylation and simulated phenotypic data based on varying sample sizes and varying the true amount of variance explained by methylation and the true amount of variance explained by SNPs. Horizontal line shows where proportion of significant estimates is 0.05 . 


\section{Discussion}

Overall, we found significant associations between DNA methylation and phenotype for four of the seven traits measured in this study (plant height, leaf lobedness, disease susceptibility, and trichome density). The phenotypic traits varied in their association with DNA methylation based on sequence context, with traits such as height associated with $\mathrm{mCHG}$ and $\mathrm{mCHH}$ methylation, while leaf lobedness associated most strongly with mCG sites. In addition, the amount of variation explained by DNA methylation was substantially reduced in some cases after controlling for genetic variation in SNPs, indicating that variation in DNA methylation and genomic background may be confounded in some instances. Resolving the associations between methylation and phenotypic traits is important for understanding the role of epigenetic modifications in plant response to the environment. This study provides one of the few examples of significant associations between DNA methylation and phenotype for a tree species.

The height of 4-year-old valley oak saplings showed strong associations with variation in $\mathrm{mCHG}$ and $\mathrm{mCHH}$ methylation and no associations with SNPs or mCG methylation. When we adjusted height to control for local environmental effects (i.e., differences within and across common gardens), the significant association between height and mCHG and $\mathrm{mCHH}$ no longer remained. In general, plant height and growth are plastic traits largely influenced by environmental conditions experienced by individual plants, though growth in valley oak can be partially explained by SNP variation [76]. The fact that the association between DNA methylation and height was removed after controlling for plastic phenotypic responses suggests $\mathrm{mCHG}$ and $\mathrm{mCHH}$ methylation exhibit plastic responses to the environment even within common gardens, which correspond to changes in plant height. A previous experimental study where valley oak seedlings that were chemically demethylated suggests a potential mechanistic link between DNA methylation and plant height in valley oaks [31]. When DNA methylation was reduced in all sequence contexts, seedlings showed a $\sim 50 \%$ reduction in new growth compared to controls [31]. Furthermore, associations between DNA methylation and plant growth have been demonstrated in other systems, including Eucalyptus [34,77,78], suggesting that plant growth may be a phenotypic trait particularly sensitive to variation in DNA methylation. At the same time, plant growth is also a fitness component which may reflect the consequences of traits on plant performance rather than a direct effect on polygenic traits associated with growth.

Leaf lobedness, a trait associated with leaf hydraulic resistance [58], showed strong associations with variation in both SNPs and $\mathrm{mCG}$ methylation, but no association with $\mathrm{mCHG}$ or $\mathrm{mCHH}$ methylation. Leaf lobedness has been shown to vary across natural populations spanning the valley oak range [79] and to be positively associated with photosynthetic rates [80], and thus might be a target of divergent selection. Our results support the idea that leaf lobedness is a heritable trait where variation in SNPs explain a significant amount of variation. In addition, $\mathrm{mCG}$ methylation by itself explained variation in leaf lobedness, though this amount was reduced when also controlling for variation in SNPs. Given that mCG methylation itself can be heritable, it seems likely that the association between mCG methylation and leaf lobedness is driven by an underlying correlation between variation in mCG methylation and SNPs. Because most CG methylation is in gene bodies and it has been shown that gene body methylation may not directly influence gene expression, the reason for this association will need more investigation. Indeed, the underlying causal mechanism driving phenotypic variation is likely to be more associated with the genomic background rather than $\mathrm{mCG}$ methylation itself. Similarly, trichome density also varies across populations in the valley oak range [79] and showed strong associations with variation in SNPs and all three methylation sequence contexts. The associations with sequence contexts were substantially reduced after controlling for genetic variation, suggesting that variation in SNPs is likely to be the underlying driver of variation in trichome density. However, further studies, potentially using demethylating chemical agents to experimentally manipulate methylation levels [81], are needed to conclusively 
determine causal pathways and disentangle the influence of variation in DNA methylation levels from potential confounding effects of genomic background.

Given the complexities in the way that DNA methylation is associated with phenotypic variation depending on many factors, such as context of the methylation [7], TE insertions impacts (e.g., [45]), and variation in DNA methylation homeostasis (e.g., [16]), we acknowledge the limitations in this study. Once candidate phenotypes are identified, future experimental work would be necessary to identify the mechanisms underlying the patterns reported here.

In general, studies associating DNA methylation with phenotypic traits in non-model plant systems are rare, and the sample size of 160 individuals achieved in this study are high for current standards of ecological epigenomic studies. However, such a sample size is relatively low for human studies and studies in model plant systems [82]. As a consequence, our study was limited by low statistical power and high uncertainty in estimates of percent variance explained in phenotypic traits. Because of this limitation, we advise caution in interpreting the values of percent variance explained as exact estimates and recognize that the lack of a significant association between SNPs, DNA methylation, and a phenotypic trait could arise from low statistical power rather than a lack of a true association. In addition, detecting associations between polygenic traits and variation in SNPs or DNA methylation can be difficult, relying on adequate coverage of markers across the genome and the sequenced markers being in linkage disequilibrium with causal variants or potentially casual variants themselves [83]. From our simulation analysis (Figure 3, Figure S2), samples sizes on the order of $500-1000$ would be needed to obtain $~ 75-100 \%$ statistical power depending on the strength of the association between DNA methylation and phenotypic trait. Achieving the sample sizes necessary to obtain sufficient statistical power and reduced uncertainty will become more feasible as epigenomic sequencing techniques continue to become more accessible in ecology and evolutionary biology research $[4,70]$.

In summary, this study provides compelling evidence that DNA methylation can predict variation in ecologically relevant phenotypic traits, such as plant height, leaf lobedness, disease susceptibility, and trichome density in valley oak. Future studies that combine whole-genome bisulfite sequencing, gene expression analysis, TE insertion polymorphisms and phenotypic trait associations will provide a stronger and more detailed understanding of the potential mechanistic links between methylation at particular genomic regions and phenotypic traits.

Supplementary Materials: The following are available online at https:/ /www.mdpi.com/article/ 10.3390/f12050569/s1, Figure S1: Results of PCA for SNP and DNA methylation data, Figure S2: Proportion of variance explained by simulated phenotypic and DNA methylation data.

Author Contributions: Conceptualization, L.B. and V.L.S.; methodology, L.B., B.M., S.F.-G., J.W.W., and V.L.S.; formal analysis, L.B.; resources, V.L.S. and J.W.W.; writing- original draft preparation, L.B.; writing-review and editing, L.B., B.M., S.F.-G., J.W.W., and V.L.S.; funding acquisition, V.L.S. and J.W.W. All authors have read and agreed to the published version of the manuscript.

Funding: This research was funded in part by a research award to VLS and colleagues from National Science Foundation Plant Genome Research Program (NSF IOS-\#1444661). Post-doctoral funding for LB was provided by the La Kretz Center for California Conservation Science at UCLA and the NSF award.

Institutional Review Board Statement: Not applicable.

Informed Consent Statement: Not applicable.

Data Availability Statement: The data and code used in this study are available on Figshare: https:/ / doi.org/10.6084/m9.figshare.14241884, accessed on 29 April 2021.

Acknowledgments: We acknowledge the native peoples of California as the traditional caretakers of the oak ecosystems sampled for this project. We thank Z. Celikkol, J. Basaran, C. Henriquez, D. Burge, C. Reimche, S. A. Swanson, M. Muia, A. Yoon, M. Hopkins, A. Copeland, K. Chang, A. Tiwari, C. Horn, V. Michaelis, X. Zhu, and K. Beckley for help with data collection. We are grateful for A. Delfino 
Mix, A. Lentz, A. Albarran-Laras, P. Gugger, L. Crane, and many others for their help in establishing and maintaining the valley oak provenance trial. We thank E. Eskin, B. Pasaniuc, S. Sankararaman, and members of the Sork lab for their helpful comments and discussion. Genomic studies were supported by NSF PGRP grant (IOS-1444661) to V.L.S. Provenance trials were supported by the US Department of Agriculture Forest Service Pacific Southwest Research Station. Any use of product names is for informational purposes only and does not imply endorsement by the US Government.

Conflicts of Interest: The authors declare no conflict of interest.

\section{References}

1. Sow, M.D.; Allona, I.; Ambroise, C.; Conde, D.; Fichot, R.; Gribkova, S.; Jorge, V.; Le-Provost, G.; Pâques, L.; Plomion, C.; et al. Epigenetics in forest trees: State of the art and potential implications for breeding and management in a context of climate change. In Advances in Botanical Research; Mirouze, M., Bucher, E., Gallusci, P., Eds.; Academic Press: Cambridge, MA, USA, 2018; Volume 88, pp. 387-453.

2. Carbó, M.; Iturra, C.; Correia, B.; Colina, F.J.; Meijón, M.; Álvarez, J.M.; Cañal, M.J.; Hasbún, R.; Pinto, G.; Valledor, L. Epigenetics in forest trees: Keep calm and carry on. In Epigenetics in Plants of Agronomic Importance: Fundamentals and Applications: Transcriptional Regulation and Chromatin Remodelling in Plants; Alvarez-Venegas, R., De-la-Peña, C., Casas-Mollano, J.A., Eds.; Springer International Publishing: Cham, Switzerland, 2019; pp. 381-403. ISBN 9783030147600.

3. Balao, F.; Paun, O.; Alonso, C. Uncovering the contribution of epigenetics to plant phenotypic variation in Mediterranean ecosystems. Plant Biol. 2017, 1-12. [CrossRef] [PubMed]

4. Richards, C.L.; Alonso, C.; Becker, C.; Bossdorf, O.; Bucher, E.; Colomé-Tatché, M.; Durka, W.; Engelhardt, J.; Gaspar, B.; Gogol-Döring, A.; et al. Ecological plant epigenetics: Evidence from model and non-model species, and the way forward. Ecol. Lett. 2017, 20, 1576-1590. [CrossRef]

5. Verhoeven, K.J.F.; VonHoldt, B.M.; Sork, V.L. Epigenetics in ecology and evolution: What we know and what we need to know. Mol. Ecol. 2016, 25, 1631-1638. [CrossRef] [PubMed]

6. Finnegan, E.J.; Genger, R.K.; Peacock, W.J.; Dennis, E.S. DNA methylation in plants. Annu. Rev. Plant Physiol. Plant Mol. Biol. 1998, 49, 223-247. [CrossRef] [PubMed]

7. Law, J.A.; Jacobsen, S.E. Establising, maintaining and modifying DNA methylation patterns in plants and animals. Nat. Rev. Genet. 2011, 11, 204-220. [CrossRef]

8. Bossdorf, O.; Richards, C.L.; Pigliucci, M. Epigenetics for ecologists. Ecol. Lett. 2008, 11, 106-115. [CrossRef] [PubMed]

9. Verhoeven, K.J.F.; Jansen, J.J.; van Dijk, P.J.; Biere, A. Stress-induced DNA methylation changes and their heritability in asexual dandelions. New Phytol. 2010, 185, 1108-1118. [CrossRef]

10. Zhang, Y.Y.; Fischer, M.; Colot, V.; Bossdorf, O. Epigenetic variation creates potential for evolution of plant phenotypic plasticity. New Phytol. 2013, 197, 314-322. [CrossRef]

11. Angers, B.; Castonguay, E.; Massicotte, R. Environmentally induced phenotypes and DNA methylation: How to deal with unpredictable conditions until the next generation and after. Mol. Ecol. 2010, 19, 1283-1295. [CrossRef]

12. Herrera, C.M.; Alonso, C.; Medrano, M.; Pérez, R.; Bazaga, P. Transgenerational epigenetics: Inheritance of global cytosine methylation and methylation-related epigenetic markers in the shrub Lavandula latifolia. Am. J. Bot. 2018, 105, 741-748. [CrossRef]

13. Herman, J.J.; Sultan, S.E. DNA methylation mediates genetic variation for adaptive transgenerational plasticity. Proc. Royal Soc. B 2016, 283, 20160988. [CrossRef] [PubMed]

14. Johannes, F.; Porcher, E.; Teixeira, F.K.; Saliba-colombani, V.; Albuisson, J.; Heredia, F.; Colot, V. Assessing the impact of transgenerational epigenetic variation on complex traits. PLoS Genet. 2009, 5, e1000530. [CrossRef] [PubMed]

15. Whipple, A.V.; Holeski, L.M. Epigenetic inheritance across the landscape. Front. Genet. 2016, 7, 189. [CrossRef]

16. Zhang, Y.; Wendte, J.M.; Ji, L.; Schmitz, R.J. Natural variation in DNA methylation homeostasis and the emergence of epialleles. Proc. Natl. Acad. Sci. USA 2020, 117, 4874-4884. [CrossRef]

17. Fieldes, M.A.; Amyot, L.M. Epigenetic control of early flowering in flax lines induced by 5- azacytidine applied to germinating seed. J. Hered. 1999, 90, 199-206. [CrossRef]

18. Dubin, M.J.; Zhang, P.; Meng, D.; Remigereau, M.S.; Osborne, E.J.; Casale, F.P.; Drewe, P.; Kahles, A.; Jean, G.; Vilhjálmsson, B.; et al. DNA methylation in Arabidopsis has a genetic basis and shows evidence of local adaptation. Elife 2015, 4, 1-23. [CrossRef] [PubMed]

19. Finnegan, E.J.; Peacock, W.J.; Dennis, E.S. Reduced DNA methylation in Arabidopsis thaliana results in abnormal plant development. Proc. Natl. Acad. Sci. USA 1996, 93, 8449-8454. [CrossRef]

20. Tatra, G.S.; Miranda, J.; Chinnappa, C.C.; Reid, D.M. Effect of light quality and 5-azacytidine on genomic methylation and stem elongation in two ecotypes of Stellaria longipes. Physiol. Plant. 2000, 109, 313-321. [CrossRef]

21. Bräutigam, K.; Vining, K.J.; Lafon-Placette, C.; Fossdal, C.G.; Mirouze, M.; Marcos, J.G.; Fluch, S.; Fraga, M.F.; Guevara, M.Á.; Abarca, D.; et al. Epigenetic regulation of adaptive responses of forest tree species to the environment. Ecol. Evol. 2013, 3, $399-415$. [CrossRef]

22. Brockerhoff, E.G.; Barbaro, L.; Castagneyrol, B.; Forrester, D.I.; Gardiner, B.; González-Olabarria, J.R.; Lyver, P.O.; Meurisse, N.; Oxbrough, A.; Taki, H.; et al. Forest biodiversity, ecosystem functioning and the provision of ecosystem services. Biodivers. Conserv. 2017, 26, 3005-3035. [CrossRef] 
23. Bonan, G.B. Forests and climate change: Forcings, feedbacks, and the climate benefits of forests. Science 2008, 320, 1444-1449. [CrossRef] [PubMed]

24. Beer, C.; Reichstein, M.; Tomelleri, E.; Ciais, P.; Jung, M.; Carvalhais, N.; Rödenbeck, C.; Arain, M.A.; Baldocchi, D.; Bonan, G.B.; et al. Terrestrial gross carbon dioxide uptake: Global distribution and covariation with climate. Science 2010, 329, 834-838. [CrossRef] [PubMed]

25. Cavender-Bares, J. Diversity, distribution and ecosystem services of the North American oaks. Int. Oaks 2016, $27,37-48$.

26. Platt, A.; Gugger, P.F.; Pellegrini, M.; Sork, V.L. Genome-wide signature of local adaptation linked to variable CpG methylation in oak populations. Mol. Ecol. 2015, 24, 3823-3830. [CrossRef]

27. Gugger, P.F.; Fitz-Gibbon, S.; Pellegrini, M.; Sork, V.L. Species-wide patterns of DNA methylation variation in Quercus lobata and their association with climate gradients. Mol. Ecol. 2016, 25, 1665-1680. [CrossRef] [PubMed]

28. Rico, L.; Ogaya, R.; Barbeta, A.; Peñuelas, J. Changes in DNA methylation fingerprint of Quercus ilex trees in response to experimental field drought simulating projected climate change. Plant Biol. 2014, 16, 419-427. [CrossRef] [PubMed]

29. Correia, B.; Valledor, L.; Meijón, M.; Rodriguez, J.L.; Dias, M.C.; Santos, C.; Cañal, M.J.; Rodriguez, R.; Pinto, G. Is the interplay between epigenetic markers related to the acclimation of cork oak plants to high temperatures? PLoS ONE 2013, 8, e53543. [CrossRef]

30. Ramos, M.; Rocheta, M.; Carvalho, L.; Inácio, V.; Graça, J.; Morais-Cecilio, L. Expression of DNA methyltransferases is involved in Quercus suber cork quality. Tree Genet. Genomes 2013, 9, 1481-1492. [CrossRef]

31. Browne, L.; Mead, A.; Horn, C.; Chang, K.; Celikkol, Z.A.; Henriquez, C.L.; Ma, F.; Beraut, E.; Meyer, R.S.; Sork, V.L. Experimental DNA demethylation associates with changes in growth and gene expression of oak tree seedlings. G3 2020, 10, 1019-1028. [CrossRef]

32. Yakovlev, I.A.; Asante, D.K.A.; Fossdal, C.G.; Junttila, O.; Johnsen, Ø. Differential gene expression related to an epigenetic memory affecting climatic adaptation in Norway spruce. Plant Sci. 2011, 180, 132-139. [CrossRef]

33. Liang, D.; Zhang, Z.; Wu, H.; Huang, C.; Shuai, P.; Ye, C.-Y.; Tang, S.; Wang, Y.; Yang, L.; Wang, J.; et al. Single-base-resolution methylomes of Populus trichocarpa reveal the association between DNA methylation and drought stress. BMC Genet. 2014, 15, S9. [CrossRef]

34. Jacinto Pereira, W.; de Castro Rodrigues Pappas, M.; Camargo Campoe, O.; Stape, J.L.; Grattapaglia, D.; Joannis Pappas, G., Jr. Patterns of DNA methylation changes in elite Eucalyptus clones across contrasting environments. For. Ecol. Manag. 2020, 474, 118319. [CrossRef]

35. Albaladejo, R.G.; Parejo-Farnés, C.; Rubio-Pérez, E.; Nora, S.; Aparicio, A. Linking DNA methylation with performance in a woody plant species. Tree Genet. Genomes 2019, 15, 15. [CrossRef]

36. Herrera, C.M.; Bazaga, P. Epigenetic correlates of plant phenotypic plasticity: DNA methylation differs between prickly and nonprickly leaves in heterophyllous Ilex aquifolium (Aquifoliaceae) trees. Bot. J. Linn. Soc. 2013, 171, 441-452. [CrossRef]

37. Kalisz, S.; Purugganan, M.D. Epialleles via DNA methylation: Consequences for plant evolution. Trends Ecol. Evol. 2004, 19, 309-314. [CrossRef]

38. Mirouze, M.; Paszkowski, J. Epigenetic contribution to stress adaptation in plants. Curr. Opin. Plant Biol. 2011, 14, 267-274. [CrossRef]

39. Dowen, R.H.; Pelizzola, M.; Schmitz, R.J.; Lister, R.; Dowen, J.M.; Nery, J.R.; Dixon, J.E.; Ecker, J.R. Widespread dynamic DNA methylation in response to biotic stress. Proc. Natl. Acad. Sci. USA 2012, 109, E2183-E2191. [CrossRef]

40. Niederhuth, C.E.; Schmitz, R.J. Putting DNA methylation in context: From genomes to gene expression in plants. Biochim. Biophys. Acta 2017, 1860, 149-156. [CrossRef]

41. Bewick, A.J.; Zhang, Y.; Wendte, J.M.; Zhang, X.; Schmitz, R.J. Evolutionary and experimental loss of gene body methylation and its consequence to gene expression. G3 2019, 9, 2441-2445. [CrossRef]

42. Kundariya, H.; Yang, X.; Morton, K.; Sanchez, R.; Axtell, M.J.; Hutton, S.F.; Fromm, M.; Mackenzie, S.A. MSH1-induced heritable enhanced growth vigor through grafting is associated with the RdDM pathway in plants. Nat. Commun. 2020, 11, 5343. [CrossRef]

43. Gienapp, P.; Fior, S.; Guillaume, F.; Lasky, J.R.; Sork, V.L.; Csilléry, K. Genomic quantitative genetics to study evolution in the wild. Trends Ecol. Evol. 2017, 32, 897-908. [CrossRef] [PubMed]

44. Yang, J.; Benyamin, B.; McEvoy, B.P.; Gordon, S.; Henders, A.K.; Nyholt, D.R.; Madden, P.A.; Heath, A.C.; Martin, N.G.; Montgomery, G.W.; et al. Common SNPs explain a large proportion of the heritability for human height. Nat. Genet. 2010, 42, 565-569. [CrossRef] [PubMed]

45. Domínguez, M.; Dugas, E.; Benchouaia, M.; Leduque, B.; Jiménez-Gómez, J.M.; Colot, V.; Quadrana, L. The impact of transposable elements on tomato diversity. Nat. Commun. 2020, 11, 4058. [CrossRef] [PubMed]

46. Thomson, C.E.; Winney, I.S.; Salles, O.C.; Pujol, B. A guide to using a multiple-matrix animal model to disentangle genetic and nongenetic causes of phenotypic variance. PLOS ONE 2018, 13, e0197720. [CrossRef] [PubMed]

47. Yang, J.; Lee, S.H.; Goddard, M.E.; Visscher, P.M. GCTA: A tool for genome-wide complex trait analysis. Am. J. Hum. Genet. 2011, 88, 76-82. [CrossRef]

48. Sork, V.L.; Cokus, S.J.; Fitz-Gibbon, S.T.; Zimin, A.V.; Puiu, D.; Garcia, J.A.; Gugger, P.F.; Henriquez, C.L.; Zhen, Y.; Lohmueller, K.E.; et al. High-quality genome and methylomes illustrate features underlying evolutionary success of oaks. bioRxiv 2021. [CrossRef] 
49. Niederhuth, C.E.; Bewick, A.J.; Ji, L.; Alabady, M.S.; Kim, K.D.; Li, Q.; Rohr, N.A.; Rambani, A.; Burke, J.M.; Udall, J.A.; et al. Widespread natural variation of DNA methylation within angiosperms. Genome Biol. 2016, 17, 194. [CrossRef]

50. Pavlik, B.M.; Muick, P.C.; Johnson, S.G.; Popper, M. Oaks of California; Cachuma Press: Los Olivos, CA, USA, 1991.

51. Anderson, M.K. Indigenous Uses, Management, and Restoration of Oaks of the Far Western United States; Natural Resources Conservation Service, National Plant Center, United States Department of Agriculture: Washington, DC, USA, 2007.

52. Gugger, P.F.; Ikegami, M.; Sork, V.L. Influence of late Quaternary climate change on present patterns of genetic variation in valley oak, Quercus lobata Nee. Mol. Ecol. 2013, 22, 3598-3612. [CrossRef]

53. Sork, V.L.; Davis, F.W.; Westfall, R.; Flint, A.; Ikegami, M.; Wang, H.; Grivet, D. Gene movement and genetic association with regional climate gradients in California valley oak (Quercus lobata Nee) in the face of climate change. Mol. Ecol. 2010, 19, 3806-3823. [CrossRef]

54. Delfino Mix, A.; Wright, J.W.; Gugger, P.F.; Liang, C.; Sork, V.L. Establishing a range-wide provenance test in valley oak (Quercus lobata Née) at two California sites. In Proceedings of the Seventh Oak Symposium: Managing Oak Woodlands in a Dynamic World; General Technical Report PSW-GTR-251; Standiford, R.B., Purcelll, K.L., Eds.; U.S. Department of Agriculture, Forest Service, Pacific Southwest Research Station: Berkeley, CA, USA, 2015; pp. 413-424.

55. MacDonald, B.W. Local Climatic Heterogeneity Predicts Differences in Phenotypic Plasticity across Populations of a WidelyDistributed California Oak Species. Master's Thesis, University of California, Los Angeles, CA, USA, 2017.

56. Sage, R.D.; Koenig, W.D.; McLaughlin, B.C. Fitness consequences of seed size in the valley oak Quercus lobata Née (Fagaceae). Ann. For. Sci. 2011, 68, 477. [CrossRef]

57. Rueden, C.T.; Schindelin, J.; Hiner, M.C.; DeZonia, B.E.; Walter, A.E.; Arena, E.T.; Eliceiri, K.W. ImageJ2: ImageJ for the next generation of scientific image data. BMC Bioinform. 2017, 18, 529. [CrossRef] [PubMed]

58. Sisó, S.; Camarero, J.; Gil-Pelegrín, E. Relationship between hydraulic resistance and leaf morphology in broadleaf Quercus species: A new interpretation of leaf lobation. Trees 2001, 15, 341-345. [CrossRef]

59. Pérez-Harguindeguy, N.; Díaz, S.; Lavorel, S.; Poorter, H.; Jaureguiberry, P.; Bret-Harte, M.S.; Cornwell, W.K.; Craine, J.M.; Gurvich, D.E.; Urcelay, C.; et al. New handbook for standardized measurment of plant functional traits worldwide. Aust. J. Bot. 2013, 23, 167-234. [CrossRef]

60. Niinemets, Ü. Global-scale climatic controls of leaf dry mass per area, density, and thickness in trees and shrubs. Ecology 2001, 82, 453-469. [CrossRef]

61. Gianfagna, T.J.; Carter, C.D.; Sacalis, J.N. Temperature and photoperiod influence trichome density and sesquiterpene content of Lycopersicon hirsutum f. Hirsutum. Plant Physiol. 1992, 100, 1403-1405. [CrossRef]

62. Picotte, J.J.; Rosenthal, D.M.; Rhode, J.M.; Cruzan, M.B. Plastic responses to temporal variation in moisture availability: Consequences for water use efficiency and plant performance. Oecologia 2007, 153, 821-832. [CrossRef]

63. Ning, P.; Wang, J.; Zhou, Y.; Gao, L.; Wang, J.; Gong, C. Adaptional evolution of trichome in Caragana korshinskii to natural drought stress on the Loess Plateau, China. Ecol. Evol. 2016, 6, 3786-3795. [CrossRef]

64. Bates, D.; Mächler, M.; Bolker, B.M.; Walker, S.C. Fitting linear mixed-effects models using lme4. J. Stat. Softw. 2015, 67, 1-48. [CrossRef]

65. Li, J.T.; Yang, J.; Chen, D.C.; Zhang, X.L.; Tang, Z.S. An optimized mini-preparation method to obtain high-quality genomic DNA from mature leaves of sunflower. Genet. Mol. Res. 2007, 6, 1064-1071.

66. Feng, S.; Rubbi, L.; Jacobsen, S.E.; Pellegrini, M. Determining DNA methylation profiles using sequencing. Methods Mol. Biol. 2011, 733, 223-238. [CrossRef]

67. Pedersen, B.S.; Eyring, K.; De, S.; Yang, I.V.; Schwartz, D.A. Fast and accurate alignment of long bisulfite-seq reads. arXiv 2014, arXiv:1401.1129.

68. Sork, V.L.; Cokus, S.J.; Fitz-Gibbon, S.T.; Zimin, A.; Puiu, D.; Pellegrini, M.; Salzberg, S.L. Valley Oak Genomic Resources. Available online: https:/ / valleyoak.ucla.edu/genomic-resources / (accessed on 31 October 2019).

69. Andri, S. DescTools: Tools for Descriptive Statistics. Available online: https://cran.r-project.org/web/packages/DescTools / index.html (accessed on 31 October 2019).

70. Lea, A.J.; Vilgalys, T.P.; Durst, P.A.P.; Tung, J. Maximizing ecological and evolutionary insight in bisulfite sequencing data sets. Nat. Ecol. Evol. 2017, 1, 1074-1083. [CrossRef] [PubMed]

71. McKenna, A.; Hanna, M.; Banks, E.; Sivachenko, A.; Cibulskis, K.; Kernytsky, A.; Garimella, K.; Altshuler, D.; Gabriel, S.; Daly, M.; et al. The Genome Analysis Toolkit: A Map Reduce framework for analyzing next-generation DNA sequencing data. Genome Res. 2010, 20, 1297-1303. [CrossRef] [PubMed]

72. Danecek, P.; Auton, A.; Abecasis, G.; Albers, C.A.; Banks, E.; DePristo, M.A.; Handsaker, R.E.; Lunter, G.; Marth, G.T.; Sherry, S.T.; et al. The variant call format and VCFtools. Bioinformatics 2011, 27, 2156-2158. [CrossRef] [PubMed]

73. Purcell, S.; Neale, B.; Todd-Brown, K.; Thomas, L.; Ferreira, M.A.R.; Bender, D.; Maller, J.; Sklar, P.; de Bakker, P.I.W.; Daly, M.J.; et al. PLINK: A tool set for whole-genome association and population-based linkage analyses. Am. J. Hum. Genet. 2007, 81, 559-575. [CrossRef] [PubMed]

74. Zhang, F.; Chen, W.; Zhu, Z.; Zhang, Q.; Nabais, M.F.; Qi, T.; Deary, I.J.; Wray, N.R.; Visscher, P.M.; McRae, A.F.; et al. OSCA: A tool for omic-data-based complex trait analysis. Genome Biol. 2019, 20, 107. [CrossRef] 
75. Main, B.J.; Lee, Y.; Ferguson, H.M.; Kreppel, K.S.; Kihonda, A.; Govella, N.J.; Collier, T.C.; Cornel, A.J.; Eskin, E.; Kang, E.Y.; et al. The genetic basis of host preference and resting behavior in the major African malaria vector, Anopheles arabiensis. PLoS Genet. 2016, 12, e1006303. [CrossRef]

76. Browne, L.; Wright, J.W.; Fitz-Gibbon, S.; Gugger, P.F.; Sork, V.L. Adaptational lag to temperature in valley oak (Quercus lobata) can be mitigated by genome-informed assisted gene flow. Proc. Natl. Acad. Sci. USA 2019, 116, 25179-25185. [CrossRef]

77. Bossdorf, O.; Arcuri, D.; Richards, C.L.; Pigliucci, M. Experimental alteration of DNA methylation affects the phenotypic plasticity of ecologically relevant traits in Arabidopsis thaliana. Evol. Ecol. 2010, 24, 541-553. [CrossRef]

78. Kanchanaketu, T.; Hongtrakul, V. Treatment of 5-azacytidine as DNA demethylating agent in Jatropha curcas L. Kasetsart J-Nat. Sci. 2015, 49, 524-535.

79. MacDonald, B.W.S.; Wright, J.W.; Sork, V.L. Local climatic Heterogeneity Predicts Differences in Phenotypic Plasticity across Populations of a Widely-Distributed California Oak, Quercus lobata Nee; In preparation.

80. Ramirez, H.-L.; Ivey, C.T.; Wright, J.W.; MacDonald, B.W.S.; Sork, V.L. Variation in leaf shape in a Quercus lobata common garden: Tests for adaptation to climate and physiological consequences. Madrono 2020, 67, 77-84. [CrossRef]

81. Griffin, P.T.; Niederhuth, C.E.; Schmitz, R.J. A comparative analysis of 5-Azacytidine- and zebularine-induced DNA demethylation. G3 2016, 6, 2773-2780. [CrossRef] [PubMed]

82. Visscher, P.M.; Hemani, G.; Vinkhuyzen, A.A.E.; Chen, G.-B.; Lee, S.H.; Wray, N.R.; Goddard, M.E.; Yang, J. Statistical power to detect genetic (co)variance of complex traits using SNP data in unrelated samples. PLoS Genet. 2014, 10, e1004269. [CrossRef] [PubMed]

83. Wray, N.R.; Yang, J.; Hayes, B.J.; Price, A.L.; Goddard, M.E.; Visscher, P.M. Pitfalls of predicting complex traits from SNPs. Nat. Rev. Genet. 2013, 14, 507-515. [CrossRef] [PubMed] 